\title{
Comparison between the Tilley-Terry and Pepsin-Cellulase Methods, used to Predict the Digestibility of some Minor By-Products in Ruminants
}

\author{
Ana CIŞMILEANU ${ }^{* 1)}$, Cătălin DRAGOMIR ${ }^{1)}$, Smaranda TOMA ${ }^{1,2)}$, \\ Horia GROSU ${ }^{1,2)}$, Eugenia MIRCEA ${ }^{13}$ \\ ${ }^{1)}$ National Research Development Institute for Animal Biology and Nutrition (IBNA), Balotesti, Romania \\ ${ }^{2)}$ University of Agronomic Sciences and Veterinary Medicine Bucharest, Romania \\ *Corresponding author, email: ana_cismileanu@yahoo.com
}

Bulletin UASVM Animal Science and Biotechnologies 72(1) / 2015

Print ISSN 1843-5262; Electronic ISSN 1843-536X

DOI:10.15835/buasvmcn-asb:10863

\begin{abstract}
While in vitro digestibility of the ruminants' feeds is classically measured by Tilley-Terry (TT) method, more operative and simple enzymatic methods, such as pepsin-cellulase (PC) were alternatively developed. Use of PC was previously validated for the main groups of feeds, but less data are available for less known, "minor" byproducts. The aim of this experiment was to assess the correlation between the digestibility of some minor byproducts sampled from the Romanian feed market (winery by-products, protein meals), estimated both by TT and PC methods. The results revealed a very high similarity between the digestibility data obtained by this two methods (R squared $=0.9648$ and $\mathrm{RSD}=4.229$ ). The conclusion is that PC method can reasonably replace the TilleyTerry method to determine the total tract digestibility of minor by-products.
\end{abstract}

Keywords: digestibility, pepsin-cellulase method, ruminants

\section{INTRODUCTION}

In ruminants, organic matter digestibility (OMD) can be fairly predicted by in vitro methods, which simulate total tract digestion. The classical in vitro method is Tilley-Terry (TT) method (1963). It is mostly used for research purposes, not for routine testing, since it requires fistulated animals and highly qualified personnel. Therefore, various enzymatic in vitro methods were developed over time, which gave similar results with TT. This similarity has been verified for regular feeds, while particular feeds may lead to biased results. Pepsin-cellulase (PC) is a two-stage enzymatic method developed by Aufrere (1982) that could conveniently replace the classic TT and it is currently used in Romania.

\section{AIMS AND OBJECTIVES}

The aim of this study was to evaluate whether the PC method can replace the TT method when assessing OMD of a set of minor, less known, byproducts sampled from the Romanian feed market.

\section{MATERIALS AND METHODS}

A total of 14 samples of the mentioned byproducts (grape marc, grape peels, grape seeds meal, camelina meal, pumpkin seeds meal, poppy seeds meal, wheat germs meal and linseed meal) were tested. These by-products were chosen on the basis of their occurrence on the Romanian feed market, opportunity to be used in ruminants' diets and scarceness of data on their digestibility measured by TT and PC. Soya meal was used as feed reference. OMD of these by-products was estimated in parallel by Tilley-Terry (1963), for the classical method $\left(\mathrm{OMD}_{\mathrm{TT}}\right)$ and by de Boever (1988), for the alternative, pepsin-cellulase method $\left(\mathrm{OMD}_{\mathrm{PC}}\right)$. MINITAB software was used to perform the t- test on differences between $\mathrm{OMD}_{\mathrm{TT}}$ and $\mathrm{OMD}_{\mathrm{PC}}$ and for assessing regression between TT and PC data.

\section{RESULTS AND DISCUSSION}

Table 1 shows OMD data, assessed by TT and PC. For winery by-products there were differences 
Tab. 1. Tilley-Terry and Pepsin-Cellulase digestibility of the studied feeds

\begin{tabular}{lcccc}
\hline Feed by-products & $\mathrm{OMD}_{\mathrm{TT}}(\%)$ & $\mathrm{OMD}_{\mathrm{pC}}(\%)$ & $\mathrm{TT}-\mathrm{PC}(\%)$ & $\mathrm{p}$ \\
\hline grape marc & $25.3 \pm 1.67$ & $21.43 \pm 2.07$ & 3.87 & $0.025>\mathrm{p}>0.01$ \\
\hline grape peels & $26.33 \pm 0.50$ & $22.68 \pm 1.82$ & 3.65 & $0.050>\mathrm{p}>0.025$ \\
\hline grape seeds meal & $19.16 \pm 0.16$ & $19.18 \pm 0.74$ & 0.02 & $\mathrm{p}>0.500$ \\
\hline camelina meal & $63.53 \pm 5.44$ & $59.12 \pm 3.72$ & 4.41 & $0.4>\mathrm{p}>0.2$ \\
\hline pumpkin seeds meal & $48.90 \pm 0.40$ & $45.78 \pm 3.29$ & 3.12 & $0.2>\mathrm{p}>0.1$ \\
\hline poppy seeds meal & $49.39 \pm 0.38$ & $50.65 \pm 0.52$ & -1.26 & $\mathrm{p}>0.500$ \\
\hline wheat germs meal & $64.79 \pm 0.21$ & $69.99 \pm 0.35$ & -5.2 & $\mathrm{p}<0.001$ \\
\hline linseed meal & $55.41 \pm 0.07$ & $63.11 \pm 0.23$ & -7.7 & $\mathrm{p}<0.001$ \\
\hline soya meal & $80.27 \pm 0.94$ & $80.30 \pm 0.29$ & -0.03 & $\mathrm{p}>0.500$ \\
\hline
\end{tabular}

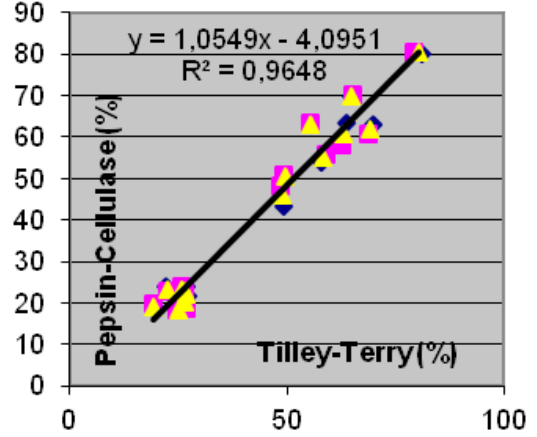

Fig. 1. Relationship between Tilley-Terry and PepsinCellulase digestibility values on tested feeds.

of maximum 3.87 digestibility points. $\mathrm{OMD}_{\mathrm{TT}}$ values were smaller than the dry mater digestibility values of 31-34\%, obtained by Molina-Alcaide (2008) and also, than the AZF 2011 (French database) values, of $29.9 \%$ in vivo OMD. A possible explication is the variability of the raw materials and their processing. In our samples, the crude protein content of our samples being lower than in the literature $(115-121 \mathrm{~g} / \mathrm{kg})$, while NDF content was higher than in the literature $(616-729 \mathrm{~g} / \mathrm{kg})$.For protein rich by-products, the differences between $\mathrm{OMD}_{\mathrm{TT}}$ and $\mathrm{OMD}_{\mathrm{PC}}$ were more variable, between 1.26 and 7.7 digestibility points. This might be due to the higher fat content $(129-203 \mathrm{~g} / \mathrm{kg})$, which could have influenced the incubation with ruminal liquid. The $\mathrm{OMD}_{\mathrm{PC}}$ values were regressed against $\mathrm{OMD}_{\text {Tт }}$ data. The obtained linear regression equation (fig. 1) had a R2 value of 0.9648 , greater than 0.90 , suggesting acceptable accuracy and precision. The residual RSD value had a low value of 4.229 , indicating good correlation between the linear function and the experimental values. The conclusion was that the enzymatic method was at least good as rumen liquid method in predicting in vitro OMD with small differences between low protein and high protein feeds.

\section{CONCLUSION}

Because simple digestibility prediction methods are necessary for practical use, PC can reasonably replace the Tilley-Terry method (R2=0.9648) to assess the total tract digestibility of minor by-products. The PC method can be widely used by commercial, less equipped feed testing laboratories, this leading to a more efficient use of the concerned feeds in ruminants diets. The PC enzymatic method has a high potential for routine analysis.

Acknowledgements. This paperwaspublished under the frame of European Social Found, Human Resources Development Operational Progr. 20072013, POSDRU/159/1.5/S/132765

\section{REFERENCES}

1. Aufrere J (1982). Etude de la prevision de la digestibilite des fourrages par une methode enzymatique, Ann. Zootech., 31(2), 111-130.

2. AFZ (Association Française de Zootechnie) (2011). La Banque de données de l'Alimentation Animale / French feed database.

3. De Boever JL, BG Cottyn, JI Andries, FX Buysse and JM Vanacker (1988). The use of a cellulase technique to predict digestibility, metabolizable and net energy of forages. Anim. Feed Sci. Technol., 19:247-260.

4. Molina-Alcaide Eduarda, A Moumen, AI Martin-Garcia (2008). By-products from viticulture and the wine industry: potential as sources of nutrients for ruminants, Journal of the Science of Food and Agriculture, 88:597604.

5. Tilley JMA, Terry RA (1963). A two-stage technique for the in vitro digestion of forage crops. J. Brit. Grassl.Soc., 18, 104-111. 